\title{
From Charles and Francis Darwin to Richard Nixon: The Origin and Termination of Anti-plant Chemical Warfare in Vietnam
}

\author{
Matthew Meselson
}

\begin{abstract}
Anti-plant chemical warfare (CW), the use of chemicals to clear vegetation or destroy food crops as a method of warfare, was conducted on a large scale in the Vietnam War of the 1960s and 1970s. Unlike the anti-personnel CW of World War I, which continued until the Armistice, anti-plant CW in Vietnam was terminated while the war was still underway. Already subject to increasing controversy, its limitation and subsequent termination was precipitated by the appearance in late 1969 of a government-sponsored study suggesting that 2,4,5-T, a component of Agent Orange, the herbicide most heavily used for defoliation, might be teratogenic to humans. In consequence, its use in Vietnam was restricted and then prohibited altogether. Although another herbicide, Agent White, remained briefly in use, all large-area defoliation had ceased by May 1970, leaving crop destruction as the remaining form of large-area herbicide operations in Vietnam. After a review of the program requested by the U.S. Ambassador and the Commanding General in Saigon, the ambassador telegraphed Washington in early December 1970 their decision that chemical crop destruction should be phased out. Although secret, the content of the telegram became known to the press and was published a week later, followed shortly thereafter by President Richard Nixon's announcement that there would be "an orderly yet rapid phaseout of herbicide operations in Vietnam."
\end{abstract}

The development of anti-plant chemical warfare $(\mathrm{CW})$ may be traced to discoveries made by Charles Darwin and his son Francis, described in their book "The Power of Movement in Plants," published in 1880 (Darwin and Darwin 1880; Holland et al. 2009). They found that the bending of oat and canary grass seedlings (specifically, the cotyledons) toward a light source does not occur if the tip of the seedling is shielded from light or excised. Observing that the bending occurs a short distance away from the tip, they concluded that "some influence is transmitted from the upper to the lower part, causing the latter to bend." They also repeated and

M. Meselson $(\bowtie)$

Department of Molecular and Cellular Biology, Harvard University, Cambridge, MA, USA

e-mail: msm@wjh.harvard.edu

(C) The Author(s) 2017

B. Friedrich et al. (eds.), One Hundred Years of Chemical Warfare: Research,

Deployment, Consequences, DOI 10.1007/978-3-319-51664-6_17 
confirmed disputed experiments by others, showing that the downward bending of roots in response to gravity is likewise "due to an influence transmitted from the apex to the adjoining part where the bending takes place."

Investigations early in the twentieth century showed the "influence" to be a material substance. Bending in response to light was found not to occur if the tip is separated by a thin sheet of mica from the region where bending would otherwise occur but does occur if the severed parts are separated instead by a layer of gelatin, through which a chemical substance might diffuse. The isolation and identification of the presumed substance was facilitated by the further discovery that a small block of agar that has been placed on the upper cut surface of a seedling cut through near the tip, when placed on one side of the lower surface, causes bending in the direction away from that side. This was interpreted to mean that a growth-promoting substance adsorbed in the agar block is transported downward on that side of the seedling, where it causes the observed bending. The angle of bending under defined conditions provided a quantitative assay for the growth-promoting substance that was then used to guide its isolation from two sources known to have such activity: human urine and the fungus Rhizopus suinis. The highly active substance isolated from both sources was found to be indole-3-acetic acid (IAA). Only much later was it established that IAA is the major naturally-occurring plant hormone involved in heliotropism and geotropism (Whippo and Hangarter 2006; Abel and Theologis 2010; Enders and Strader 2015).

Although IAA stimulates plant growth at low doses, higher doses were found to cause plant death. In 1941, Ezra J. Kraus, chair of the Botany Department at the University of Chicago, proposed that plant growth regulators might therefore find use as selective herbicides in agriculture and began a screen for compounds more stable than IAA that might be used for such purposes. Following Kraus' suggestion, a parallel screening program was undertaken at the U.S. Agricultural Research Center at Beltsville, Maryland under the direction of one of his former doctoral students. Late that year, in a memo written a few days after U.S. entry into WWII, Kraus proposed to a committee of the National Academy of Sciences formed to advise the War Department on biological warfare that a program be established to develop herbicides that might provide a "simple means of destruction of rice crops, the staple food supply of the Japanese" and which applied as "sprays or mists over enemy forests would, through the killing of trees, reveal concealed military depots" (Kraus 1942; Peterson 1967; Troyer 2001).

It had been found in 1942 that 2,4-dichlorophenoxyacetic acid $(2,4-D)$ is a potent stimulator of plant growth (Zimmerman and Hitchcock 1942). But its powerful herbicidal activity and potential as a weed killer, discovered independently in Britain and in the U.S., remained secret until late in the war. Kraus, upon learning of the plant growth activity of 2,4-D, included it in the screens underway at Chicago and at Beltsville, thereby becoming one of the discoverers of its potential for use as an herbicide (Troyer 2001). Conducted under conditions of wartime secrecy, the work at Chicago was done in the University's botany department, just around the corner from the west stands of the track and football field where in the 
winter of 1942 Enrico Fermi and his colleagues were building the world's first nuclear reactor.

Starting in 1944, a large-scale project to screen chemicals for herbicidal activity and for plant species specificity and to develop methods for their military application was begun by the U.S. Army Chemical Warfare Service at the Army Biological Research Center at Camp (later Fort) Detrick, Maryland, established the year before. The main effort was on crop destruction with only limited work on defoliation. By late 1945, some one thousand substances had been tested for use against various food crops at Detrick or under its direction in field tests elsewhere in the U.S. Of the agents tested, 2,4-D and 2,4,5-trichlorophenoxyacetic acid (2,4,5-T) were considered to be the most effective, although later work showed them to be less so against grain crops. By the end of the war, substantial stocks of 2,4-D and other herbicides and equipment for their dissemination by aircraft had been procured but were not used in any theater. After the war, except for a severe cutback in 1957, reversed the following year, research and field testing continued on a substantial scale. Following aerial spray tests conducted in the 1950s at the U.S. Army chemical and biological proving grounds at Dugway, Utah, and in 1959 at Camp Drum, New York, formulations of 2,4-D and 2,4,5-T were chosen as defoliants and the plant metabolic disrupter and desiccant cacodylic acid (dimethylarsenic acid), more toxic for grain crops, was selected for use against rice and wheat (Cecil 1986; Young 2009).

Thus, unlike the anti-personnel CW of World War I, which began with little prior development and no established advocate organization within the military, anti-plant CW in Vietnam was preceded by many years of research, development, and testing by a dedicated organization within the U.S. Army. Further, a precedent had been set for anti-plant CW by the use of herbicides, mainly $2,4,5-\mathrm{T}$, for crop destruction and defoliation in British counterinsurgency operations in Malaya in the early 1950s (Connor and Thomas 1984).

Experimental testing of chemical crop destruction and defoliation in Vietnam began in August 1961 and continued until mid-January 1962 as part of Project Agile of the U.S. Defense Department's Advanced Research Projects Agency (ARPA), supported by the Crops Division of the Army Chemical Corps at Detrick (Brown 1962). The initial impetus for introducing herbicide warfare in Vietnam appears to have come from William H. Godel, an ARPA Deputy Director acting with the encouragement of Vietnam President Ngo Dinh Diem and assisted by the director of Detrick's Crops Division (FRUS 1961; Godel 1961; Brown 1962; Bundy 1972; Washington Post 1966). In the first tests, on August 10, 1961, a mixture of the n-butyl esters of 2,4-D and 2,4,5-T and the isopropyl ester of 2,4,5-T, known as Agent Purple, was sprayed by helicopter over manioc and rice fields and over roadside trees. While the tests were still underway, the Chief of the U.S. Military Assistance Advisory Group recommended to the Department of Defense in Saigon in October 1961 that defoliation and crop destruction be carried out against several designated targets (Olenchuk et al. 1963). In the following month, the Joint Chiefs endorsed a plan developed in Saigon to spray 334 square miles of manioc and rice with 2,4,5-T and cacodylic acid and defoliate 200 square miles of forest 
with 2,4-D and 2,4,5-T, warning, with respect to crop destruction, that "care must be taken to assure that the United States does not become the target for charges of employing chemical or biological warfare" (Buckingham 1982).

Late that same month, on November 30, 1961, responding to recommendations from the Deputy Secretary of Defense and the Secretary of State, President Kennedy agreed in principle to chemical defoliation and crop destruction in Vietnam, but on a far more limited and tightly controlled basis than had been envisaged by the Joint Chiefs, authorizing only a

selective and carefully controlled joint (with the Republic of Vietnam) program of defoliant operations $[\ldots]$ proceeding thereafter to food denial only if the most careful basis of resettlement and alternative food supply has been created (Bundy 1961; Buckingham 1982).

Limited defoliation on an operational basis (intended to have a military effect rather than being only developmental) was begun early in January, after Kennedy reduced to only 16 miles the plan for defoliation of about 300 miles of roadside that had been submitted to him by the Departments of Defense and State. Authority to approve defoliation missions was retained in Washington until November 1962, when authority for defoliation of limited areas was delegated to the U.S. ambassador and the commander of U.S. forces in Vietnam, followed in May 1963 by the delegation to them of authority for all defoliation. Crop destruction was not authorized until October 1962. It required State and Defense Department authorization throughout the Kennedy administration and until July 1964, when it was delegated to Saigon (Collins 1967; Warren 1968; Clary 1971; Buckingham 1982; Cecil 1986).

Altogether, according to updated estimates, about 73 million liters of various herbicides were sprayed by fixed-wing aircraft and helicopters over an area of approximately $26,000 \mathrm{~km}^{2}, 15$ percent of the land area of the Republic of Vietnam, most of it sprayed more than once. Most of the area sprayed was coastal or inland forest while about $10 \%$ was crop land. Of the total volume sprayed, about $63 \%$ was Agent Orange (a mixture of the n-butyl esters of 2,4-D and 2,4,5-T or, in smaller quantity, containing the iso-octyl rather than the n-butyl ester of 2,4,5-T), 28\% Agent White (a mixture of 2,4-D and a chlorinated derivative of picolinic acid plus inert ingredients), and 7\% Agent Blue (cacodylic acid and its sodium salt plus inert ingredients), and a few percent of other compounds or formulations that were employed mostly before the introduction of Agent Orange in 1965. After a gradual buildup in herbicide operations in earlier years, nearly $80 \%$ was dispensed in the four years 1966-1969, followed by a sharp drop in 1970, after the restriction and then cancellation of authorization for the use of Agent Orange (Buckingham 1982; Westing 1984; Stellman et al. 2003; Young 2009).

The limitation and subsequent cessation of the use of Agent Orange was precipitated when a study of possible carcinogenic, teratogenic, and mutagenic effects of a large number of pesticides and industrial chemicals was brought to the attention of the administration. The study, dated August 1968 and released to the public the following year, was commissioned by the U.S. National Cancer Institute and done 
by the Bionetics Research Laboratories of Kensington Maryland (Bionetics Research Laboratories 1968). It found that 2,4,5-T administered to pregnant mice and rats consistently caused a high frequency of malformations and death in fetuses and newborns and categorized 2,4,5-T as "probably dangerous."

Although the Bionetics report would have soon come to the attention of the White House one way or another, the swiftness of the response when it was brought to the attention of the President's Science Advisor is noteworthy. In the autumn of 1969, I was given a pre-release copy of the report. Aware of articles in Saigon newspapers claiming that herbicide exposure was causing birth defects and believing that the administration should be made aware of the Bionetics report, I and two colleagues called upon Lee DuBridge, the physicist and former president of CalTech who was then President Nixon's Science Advisor (Primack and von Hippel 1974; Hay 1982). After examining the report and while I was still with him in his office, DuBridge telephoned the Deputy Secretary of Defense, David Packard (co-founder of the Hewlett Packard Corporation), and they agreed on the spot to restrict the use of 2,4,5-T. In a White House press release late that same day, October 29, DuBridge announced that the Defense Department "will restrict the use of 2,4,5-T to areas remote from population"; that the Department of Agriculture "will cancel registrations of 2,4,5-T for food crops effective January 1"; and that the Departments of Agriculture and Interior "will stop using 2,4,5-T in their own programs" (Nelson 1969a, b). A few days later, DuBridge telephoned me at Harvard to say that representatives of the Dow Chemical Company had informed him that the likely teratogen was not 2,4,5-T itself but rather a highly toxic impurity, dioxin (2,3,7,8-tetrachlorodibenzodioxin). Dow had known of its toxicity following an outbreak of chloracne among workers at a Dow facility in 1964 (Baughman 1974; Crummett 2002). Dioxin is formed as an impurity in the Dow synthesis procedure for 2,4,5-trichlorophenol, a precursor of 2,4,5-T, particularly if carried out at too high a temperature (Young 2009). Knowing this, Dow had taken precautions to keep the concentration of dioxin in 2,4,5-T below $1 \mathrm{ppm}$. As found in research done much later, the extreme toxicity of dioxin is associated with its avid binding to a molecular receptor that regulates the expression of numerous genes (IOM 2014; Sorg 2014).

It was later found that the 2,4,5-T employed by Bionetics, not produced by Dow, contained $27 \mathrm{ppm}$ of dioxin. Further tests were therefore undertaken to determine if purer 2,4,5-T also causes birth defects in rodents. Finding that 2,4,5-T containing only about $1 \mathrm{ppm}$ of dioxin did so in mice, the Secretaries of Agriculture, Interior, and Health, Education and Welfare agreed in an announcement of April 15, 1970 to suspend registrations for uses of 2,4,5-T on agricultural land and in places likely to entail direct human exposure (US Department of the Interior 1970). Simultaneously, undersecretary Packard canceled authorization for all uses of Agent Orange in Vietnam. The cancellation of Agent Orange put a stop to nearly all large-area chemical defoliation, leaving only a few occasions on which Agent White, available in only limited supply, was used in this mode, bringing an end to all defoliation, except on the perimeters of fixed US installations, in May 1970 (Buckingham 1982). 
While large-area defoliation had ceased, chemical crop destruction continued. Although strongly supported by the Joint Chiefs and the Secretary of Defense (Laird 1970), it was controversial ever since it had been conditionally authorized by President Kennedy in 1961. A 1968 interagency review of the herbicide program ordered by the U.S. ambassador in Saigon, Ellsworth Bunker, concluded that

There is evidence that food shortages, for which crop destruction efforts were partly responsible, have at times created logistical problems for the enemy [...] The main impact of crop destruction, however, falls upon the civilian population [...] An estimated $90 \%$ of the crops destroyed in 1967 were grown, not by VC/NVA military personnel, but by civilians living there (American Embassy Saigon 1968; Clary 1971; Buckingham 1982).

The year before, a study of the military utility of the crop destruction program, based on some 2400 interviews conducted with Vietnamese familiar with the activities of the Viet Cong and the North Vietnamese army concluded that "the data consistently suggest that the crop destruction program has not in any major sense denied food to the VC" and that "the crop destruction effort may well be counterproductive. The VC continue to feed themselves while the peasant bears the brunt of the deprivation" (Betts and Denton 1967).

In 1972, after all aerial herbicide operations had ceased, Packard directed the Army Corps of Engineers to conduct a study of the military utility of herbicides in Vietnam. Based on a survey of U.S. military officers who had served in Vietnam, on the association of roadside defoliation missions with recorded friendly and enemy battle fatalities, and on earlier studies, the Engineers study concluded with respect to defoliation that "[h]erbicides were useful in supporting military operations in selected instances" and that "[m]any survey responses report that the use of herbicides around the perimeter of bases and installations is the most effective use of herbicides in Vietnam." Regarding crop destruction, the study concluded that "[h] erbicides destroyed enemy crops, but the enemy was able to compensate and overcome localized food supply shortages. At most, the crop destruction program harassed the enemy" (ESSG 1972).

An example of problems encountered in attempting to distinguish fields cultivated by military units from fields cultivated by civilians for their own consumption was encountered by a colleague and myself in August 1970. For five weeks in the summer of 1970, I was in Vietnam on behalf of the American Association for the Advancement of Science as part of a small team conducting a preliminary survey of the ecological and health effects of the military use of herbicides in Vietnam-interviewing farmers, photographing sprayed and not-sprayed forest, and collecting environmental and biomedical samples for mass spectrometric analysis for dioxin at Harvard (Constable and Meselson 1971; Meselson et al. 1972; Meselson and Baughman 1973, 1974). In order to inspect an area where crop destruction had recently taken place, the medical member of our team, Dr. John Constable, and I were flown by helicopter over a river valley in one of the northern provinces where Agent Blue had been sprayed along a $15 \mathrm{~km}$ path a few days before (Fig. 1). Flying along the length of the valley on two occasions, we saw rice fields browned by the herbicide but were too high to see much evidence of habitation. As indicators that the valley 


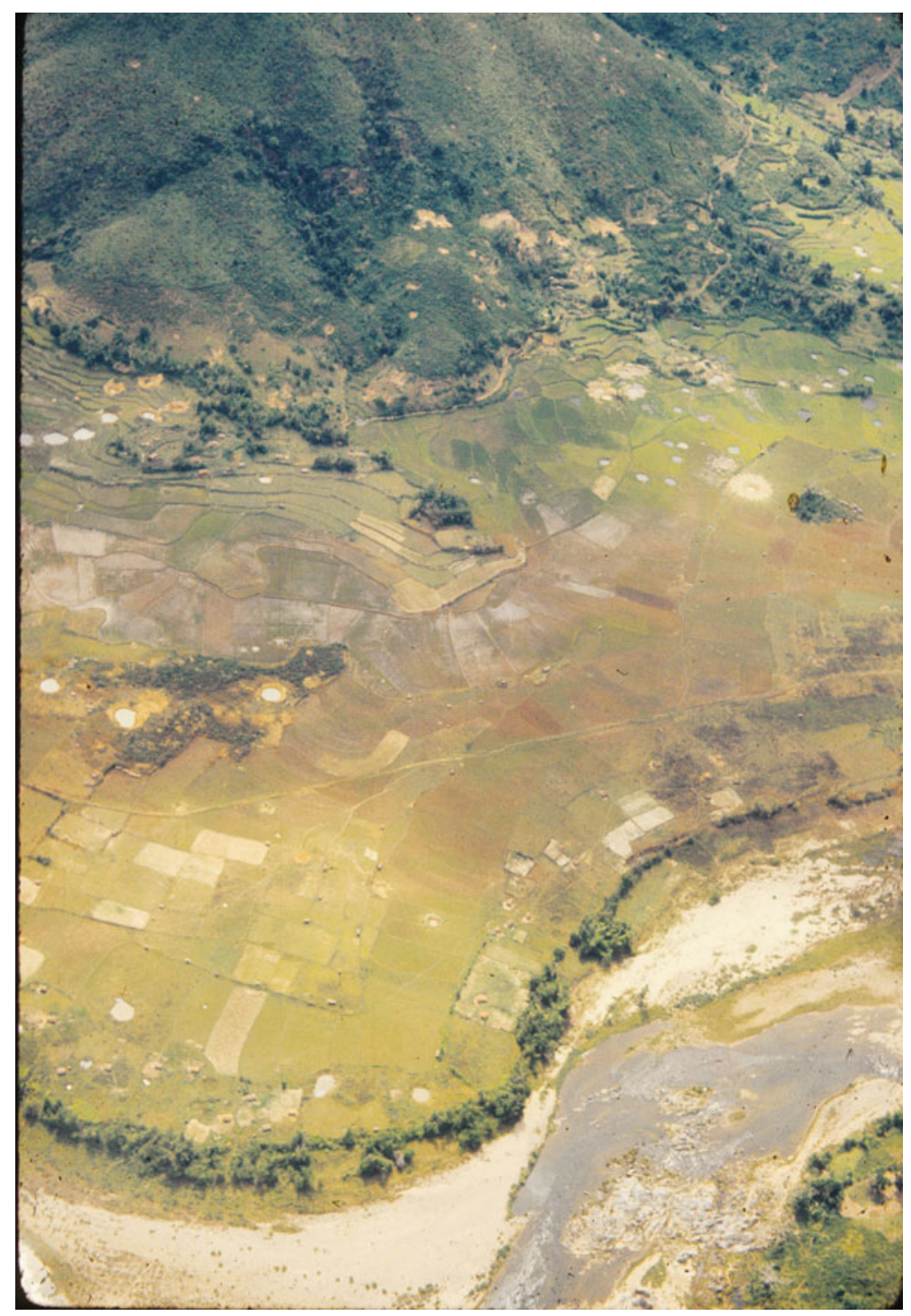

Fig. 1 Aerial photograph of a portion of a valley sprayed with Agent Blue in August 1970. Many small dwellings may be seen throughout the valley. Terraced fields may be seen on the hillsides. In order to suppress groundfire against the slow and low-flying UC-123 spray aircraft, spray missions were generally preceded by fighter aircraft delivering 500 or $750 \mathrm{lb}$ bombs, cluster bomb units, 20-mm ordnance, and/or napalm (Buckingham 1982). From the Meselson CBW Archive 


\section{AMERICAN ASSOCIATION FOR THE ADVANCEMENT OF SCIENCE}

AAAS HERBICIDE ASSESSMENT COMMISSION

BOTANICAL MUSEUM, HARVARD UNIVERSITY

CAMBRIDGE, MASSACHUSETTS O2138, U.S.A.



A.тTUR H. WEsting, Diaceto

12 November 1970

The Honorable Ellsworth Bunker

American Ambassador

Saigon, Republic of Vietnam

APO San Francisco, California 96243

Dear Ambassador Bunker,

On behalf of the Herbicide Assessment Commission of the American Association for the Advancement of Science, we wish to express our appreciation for the generous assistance provided by the Embassy during our recent tour of the Republic of Vietnam.

We are now preparing our report for presentation to the AAAS at the end of December and will send a copy to you as soon as it is available. Before that time, however, we wish to relay some observations that we believe merit your more immediate átention because they challenge the basis of the current chemical crop destruction program.

On August 21 and 28 we overflew an area in Quang Ngai province where chemical crop destruction operations had been conducted a few days before. The responsible chemical operations staff officer accompanied us on one of the overflights, and we spoke at length with other officers and civilian officials on the scene. It was explained to us that the targets were VC/NVA crop production areas and that most of the food destroyed would otherwise have been consumed by enemy forces. The reasons given for this assessment were that

1. The target area had only a very low population density.

2. The area under cultivation had expanded strikingly in recent years.

3. The cultivated area was much larger than that needed to support the small indigenous population.

4. The existence of numerous terraced rice fields indicated the influx of VC/NVA food production units, since the Montagnards who comprise the native population do not practice terracing.

Our observations are sharply at variance with all four of these points.

Fig. 2 Letter sent to Ambassador Ellsworth Bunker, General Creighton Abrams and Secretary of State William Rogers, November 12, 1970. From the Meselson CBW archive 
Background information. One of the target areas is shown in photograph 1. Three C123 aircraft sprayed herbicide along the Song Re river valley from map coordinates BS 3455 to BS 3543. The photograph was taken near the latter coordinate, looking northward up the valley. The spray swaths are generally visible as brown streaks. Spraying was conducted continuously for a distance of about ten miles, resulting in coverage of approximately 1000 acres. Photographs 2 and 3 show the ground more closely. Numerous craters have been caused by the preparatory laying down of maximum suppressive fire, including the application of 300 per cent saturation with cluster bomb units, a measure required by the seventh Airforce to protect the slow-flying Cl23's against hostile ground fire. Many dwellings may be seen in both close-ups, especially in photograph 3. The site of each of the photographs is indicated on the accompanying $1: 50,000$ scale U.S. Army map.

Population density. The map shows a high population density throughout the target area. In the twenty-seven $1 \mathrm{~km}^{2}$ grid boxes through which the spraying passed, there are more than 900 dwellings, indicated as small black squares. Detailed comparison of the map with photographs 2 and 3 suggests that the number of dwellings in the target area is at least as great as it was in 1965, the year in which the map was last revised. Assuming, for example, an occupancy of six persons per dwelling, the population in the sprayed area would be approximately 5,000. This corresponds to 180 persons per square kilometer, hardly a low population density.

Expansion of cultivated area. The boundaries of cultivated fields on the enclosed map (and also on a matching 1:20,000 scale pictomap) agree well with the boundaries seen in our photographs, offering no evidence for any major expansion of crop production since 1965. Also, the fields seen in the photographs look well established and not of recent origin.

The question of surplus. The amount of land under cultivation in the target area may be estimated from the map to be approximately 800 hectares, about one hectare for each dwelling. Contrary to the view that a large surplus of food was being grown in the valley, one hectare of mountain land is just about enough to sustain a family unit.

Significance of terraced fields. Authoritative DoD publications on the Montagnard peoples as weil as knowledgeable officials in Saigon state that the Montagnards of Quang Ngai, the Hre, have long grown rice on terraced fields.

We realize that this particular crop destruction mission may have been atypical. However, it was cited by the chemical staff officer and other officials as being particularly effective and well planned.

Moreover, our observations lend additional weight to several official studies done in Vietnam which have concluded that nearly all of the food destroyed by the chemical crop destruction program would normally be consumed by civilians, not by enemy soldiers.

Fig. 2 (continued) 
As to the scale of the present crop destruction program, we were distressed by the implications of an analysis prepared by the GVN at the province level estimating the quantity of rice and other crops marked for chemical destruction under the 1970-71 herbicide program. Including missions requested by U.S. elements as well as those requested by the Vietnamese themselves, the total quantity of food scheduled for destruction is placed at 14,575 metric tons in Quang Ngai and Quang Tin provinces alone. This should be enough to sustain some 50-70,000 persons for a year. The targets are located mainly in upland regions where Montagnards are the traditional population. The Special Commission for Highland Affairs estimates the total Montagnard population of the two provinces as just under 70,000 . Therefore if the areas we inspected are any indicator, the destruction of so much food or even of any substantial fraction of it would have devastating consequences for the Montagnard peoples of Quang Ngai and Quang Tin and for indigenous peoples in other provinces where similar conditions may prevail.

While we were in Quang Ngai province we had several occasions to interview Montagnard refugees whose lands had recently been sprayed with herbicide. We were impressed with the way in which they perceive the use of the chemicals. Apparently when the land is effected by herbicides, the Hre people consider it to be the manifestation of an evil spirit, and according to their tradition will abandon such land in the belief that it has fallen under a curse. Thus the folk beliefs of the Hre may interisify the effects of the crop destruction program on their lives.

Before leaving Vietnam we made a preliminary report of our observations to General Abrams and to Mr. Stephen Winship and Mr. Terence Grant of the Embassy Political Military section. Upon our return, one of us was requested to present a briefing at the State Department in Washington. The briefing took place on October 19 before a working level group consisting mainly of personnel from the Bureau of East Asian and Pacific Affairs and the Bureau of Intelligence and Research. We are also sending copies of this report to Secretary Rogers and to General Abrams.

We strongly hope that our observations can make a positive contribution toward bringing under review a program which seems to us very much in need of it.

Sincerely yours,

Matthew Meselson 
was an enemy food-production area, not home to a civilian population, the Chemical Corps officer who accompanied us in the helicopter and who had participated in planning the mission explained that the area under cultivation far exceeded the needs of the sparse population in the valley, that there had been a recent major expansion of rice fields, and that the presence of terraced rice fields on the hillsides, a form of rice culture practiced by ethnic Vietnamese but not by the indigenous Montagnard tribespeople, indicated that the area was an enemy crop production site.

Upon returning to the U.S., examining the high-resolution photographs we had taken from the air, comparing them with U.S. Air Force photographic coverage of the valley done in 1965 and consulting the Army's handbook on the Montagnard tribes of Vietnam and other sources, we found that all of the evidence for enemy crop production cited by the Chemical Corps officer was inaccurate or incorrectly interpreted. We therefore sent a letter describing our observations and a set of our photographs of the sprayed rice fields to Ambassador Bunker and General Creighton Abrams, Commander of U.S. forces in Vietnam and Secretary of State William Rogers (Meselson and Constable 1970) (Fig. 2). I had previously given a briefing on our observations at the State Department Bureau of Intelligence and Research and, in mid-December, had described our findings to President Nixon's National Security Advisor, Henry Kissinger (Guhin 1970; Hydle 1970; Buckingham 1982).

In November 1970, Bunker and Abrams initiated a review of the herbicide program with particular emphasis on crop destruction (Interagency 203 Committee 1970). After considering the resulting report they sent a telegram to Washington on December 9, saying they had decided that the crop destruction program should be phased out (Bunker 1970). Their recommendation leaked to the press and was published the following week (Jay 1970). On December 26, the day on which we reported our observations in Vietnam to the annual meeting of the American Association for the Advancement of Science in Chicago (Boffey 1971), President Nixon announced that "Ambassador Bunker and General Abrams are initiating a program for an orderly, yet rapid phase-out of the herbicide operations" and that during the phase-out, the use of herbicides in Vietnam would be restricted to perimeters of firebases and US installations or remote unpopulated areas (Office of the White House Press Secretary 1970). The last crop destruction mission was flown on January 7, 1971 (Cecil 1986; Young 2009). Thus, the large-area use of herbicides in Vietnam, already greatly reduced in 1970, came to an end at the start of the following year, two years before the Paris ceasefire agreement of January 1973 terminating direct US combat support for the Republic of Vietnam.

Two years later, in April 1975, President Gerald Ford proclaimed that

The United States renounces, as a matter of national policy, first use of herbicides in war except use, under regulations applicable to their domestic use, for control of vegetation within U.S. bases and installations or around their immediate defensive perimeters (Executive Order 1975). 


\section{Postscript}

While in Vietnam, I heard a spectrum of opinion from military officers, from pro to con, regarding the military utility of the herbicide program. A 1971 study conducted by the Department of Defense found that "[ $t$ ]he military utility of herbicides has been conclusively established" (FRUS 1971). Particularly noteworthy, however, was the view expressed personally to me by General Creighton Abrams in his office in Saigon on September 3, 1970. "Do you want to know what I think? I think it's shit," he said, adding that his son John, then an Army captain who had served in Vietnam during 1967-69, was of the same view. When asked why the program continued even though he was Commander of U.S. forces in Vietnam, General Abrams replied that the decision to do so was made in Washington.

Acknowledgements I am grateful to General John N. Abrams, USA, Ret. and Captain Alvin L. Young, USAF, Ret. for helpful discussions.

\section{References}

Abel, Steffen, and Athanasios Theologis. 2010. Odyssey of auxin. Cold Spring Harbor Perspectives in Biology 2010 (2): a004572.

American Embassy Saigon. 1968. Report of the Herbicide Policy Review Committee, May 28. Meselson CBW Archive, Harvard University.

Baughman, Robert W. 1974. Tetracholordibenzo-p-Dioxins in the Environment: High Resolution Mass Spectrometry at the Picogram Level. Doctoral Dissertation, Harvard University.

Betts, Russell, and Frank Denton. 1967. An Evaluation of Chemical Crop Destruction in Vietnam. RAND Corporation, Santa Monica, CA, October 11. (RM-5446-ISA/ARPA). ADA032196. http://www.rand.org/pubs/research_memoranda/RM5446-1.html.

Bionetics Research Laboratories. 1968. Evaluation of Carcinogenic, Teratogenic, and Mutagenic Activities of Selected Pesticides and Industrial Chemicals. Teratogenic Study in Mice and Rats, vol II. Washington, D.C.: U.S. Department of Commerce. NTIS PB 223 160. http://www.nal. usda.gov/exhibits/speccoll/items/show/4100.

Boffey, Philip M. 1971. Herbicides in Vietnam: AAAS study finds widespread devastation. Science 171 (3966): 43-47.

Brown, James W. 1962. Vegetational spray tests in South Vietnam. Supplement. U.S. Army Chemical Corps Biological Laboratories, Fort Detrick, MD, April. AD368997. http://www. dtic.mil/cgi-bin/GetTRDoc?Location=U2\&doc=GetTRDoc.pdf\&AD=AD0368997.

Buckingham, William A. 1982. Operation Ranch Hand: The Air Force and herbicides in Southeast Asia 1961-1971. Washington, D.C.: Office of Air Force History, United States Air Force. ADA121709. https://media.defense.gov/2010/Sep/28/2001329797/-1/-1/0/AFD100928-054.pdf.

Bundy, McGeorge. 1961. National Security Action Memorandum Number 115: Defoliant Operations in Vietnam, Nov 20. http://www.jfklibrary.org/Asset-Viewer/Z8-vBiaBdEW2Cz 9g6NUB7g.aspx.

Bundy, William P. 1972. Recorded Interview by William W. Moss. John F. Kennedy Library Oral History Program, Mar 3. http://www.jfklibrary.org/Asset-Viewer/Archives/JFKOH-MGB-04. aspx.

Bunker, Ellsworth. 1970. Telegram to Secretary of State Washington. Subject: Herbicide Policy Review, Dec 9. Saigon 19374. Meselson CBW Archive. 
Cecil, Paul F. 1986. Herbicidal warfare: The Ranch Hand Project in Vietnam. New York, London: Praeger.

Clary, James R. 1971. Project CHECO Report, Ranch Hand Herbicide Operations in SEA. Contemporary Historical Examination of Current Operations, Pacific Air Forces, July 13. ADA484753. http://www.dtic.mil/docs/citations/ADA121709.

Collins, Charles V. 1967. Project CHECO Report, Herbicide Operations in Southeast Asia, July 1961-June 1967, Oct 11. Contemporary Historical Examination of Current Operations, Pacific Air Forces. AD 779796.

Connor, Steve, and Andy Thomas. 1984. How Britain sprayed Malaya with dioxin. New Scientist 101 (1393): 6-7.

Constable, John, and Matthew Meselson. 1971. The ecological impact of large scale defoliation in Vietnam. Sierra Club Bulletin 56: 4-9.

Crummett, Warren B. 2002. Decades of dioxin: Limelight on a molecule. Bloomington, IN: Xlibris.

Darwin, Charles, and Francis Darwin. 1880. The power of movement in plants. London: John Murray.

Enders, Tara A., and Lucia C. Strader. 2015. Auxin activity: Past, present, and future. American Journal of Botany 102 (2): 180-196.

Engineer Strategic Studies Group Office (ESSG). 1972. Herbicides in military operations, vol I, February. Washington, D.C.: Department of the Army. AD893214.

Executive Order. 1975. 11850. Renunciation of Certain Uses in War of Chemical Herbicides and Riot Control Agents, April 8. 40 Federal Register 16187.

Foreign Relations of the United States, 1961-1963, vol. 1, Vietnam. 1961. Document 96. https:// history.state.gov/historicaldocuments/frus1961-63v01/d96.

Foreign Relations of the United States, 1969-1976, vol. E-2, Documents on Arms Control. 1971. Document 246. https://history.state.gov/historicaldocuments/frus1969-76ve02/d246.

Godel, W.H. 1961. Progress Report, Vietnam Combat Development and Test Center, September 13. Kennedy Papers, National Security File, Countries File, Vietnam (9/61) folder.

Guhin, Michael A. 1970. Memorandum to Henry Kissinger. Subject: Memcon of Meeting with Professor Meselson, Dec 17. Meselson CBW Archive.

Hay, Alastair. 1982. The chemical scythe. New York, London: Plenum.

Holland, Jennifer J., Diana Roberts, and Emmanuel Liscum. 2009. Understanding phototrophism: From Darwin to today. Journal of Experimental Botany 60 (7): 1969-1978.

Hydle, Lars H. 1970. U.S. State Department of Intelligence and Research. Memorandum to James D. Moffatt: Briefing by Matt Meselson on Herbicides, October 20. Meselson CBW Archive.

Institute of Medicine (IOM). 2014. Veterans and Agent Orange: Update 2012. Washington, D.C.: The National Academies Press. http://www.nap.edu/catalog/18395/veterans-and-agent-orangeupdate-2012.

Interagency 203 Committee. 1970. Report on the Herbicide Review, Nov 18. Hq. US MACV, Saigon.

Jay, Peter. 1970. US is urged to stop killing Vietnam crops. Washington Post, December 17.

Kraus, Ezra J. 1942. Plant Growth Regulators; Possible Uses, February 17. National Academy of Sciences Archives: Committees on Biological Warfare Records Group: WBC Committee: Report: Exhibit F,III. Plants 1.

Laird, Melvin. 1970. Memorandum for the Assistant to the President for National Security Affairs, Subject: United States Anticrop Warfare Program in Vietnam. With Enclosure: Assessment of the United States Anti-Crop Warfare Program in the Republic of Vietnam, July 18. Meselson CBW Archive.

Meselson, Matthew, and John Constable. 1970. Letter to Ambassador Ellsworth Bunker, November 12. Meselson CBW Archive.

Meselson, Matthew, and Robert Baughman. 1973. An analytical method for detecting TCDD (Dioxin): Levels of TCDD in samples from Vietnam. Environmental Health Perspectives 5: 27-35. http://www.ncbi.nlm.nih.gov/pmc/articles/PMC1474957/. 
Meselson, Matthew S., Arthur H. Westing, John D. Constable, and Robert E. Cook. 1972. Preliminary Report and Background Material Relevant to Presentations at the 1970 Annual Meeting of the AAAS. Congressional Record, 92nd Congress, 2nd Session, vol. 118, part 6, Mar 3, 6806-6813.

Nelson, Bryce. 1969a. Studies find danger in defoliation herbicides. Los Angeles Times, October 30.

Nelson, Bryce. 1969b. Herbicides: Order on 2,4,5-T issued at unusually high level. Science 166 (3908): 977-979.

Office of the White House Press Secretary. 1970. President's Direction to Reduce the Use of Herbicides in Vietnam. Press Release, December 26.

Olenchuk, Peter G., Robert Burke, Oran Henderson, and Wayne Davis. 1963. Task Force Saigon Herbicide Evaluation Team. Evaluation of Herbicide Operations in the Republic of Vietnam September 1962-September 1963, October 10, 71-265, San Francisco: Military Assistance Commission, Task Force Saigon Herbicide Evaluation Team.

Peterson, Gale E. 1967. The discovery and development of 2,4-D. Agricultural History 41: 243254.

Primack, Joel, and Peter von Hippel. 1974. Advice and dissent: Scientists in the political arena. New York: Basic Books.

Sorg, Oliver. 2014. AhR signalling and dioxin toxicity. Toxicology Letters 230: 225-233.

Stellman, Jeanne M., Steven D. Stellman, Richard Christian, et al. 2003. The extent and patterns of usage of Agent Orange and other herbicides in Vietnam. Nature 422: 681-687.

Troyer, James R. 2001. In the beginning: The multiple discovery of the first hormone herbicides. Weed Science 49: 290-297.

United States Department of the Interior. 1970. Press Release: Home Use of 2,4,5-T Suspended, April 15. http://www.nal.usda.gov/exhibits/speccoll/items/show/5799.

Warren, William F. 1968. A review of the herbicide program in South Vietnam. Alexandria, VA: Defense Technical Information Center, August. AD779797.

Washington Post. 1966. Embezzler Godel Sued to Repay Double, November 5, B4.

Westing, Arthur H. 1984. Herbicides in war: Past and present. In Herbicides in war, ed. Arthur H. Westing. London, Philadelphia: Taylor and Francis.

Whippo, Craig W., and Roger P. Hangarter. 2006. Phototropism: Bending towards enlightenment. The Plant Cell 18 (5): 1110-1119.

Young, Alvin. 2009. The history, use, disposition and environmental fate of Agent Orange. New York: Springer.

Zimmerman, P.W., and A.E. Hitchcock. 1942. Substituted phenoxy and benzoic acid growth substances and the relation of structure to physiological activity. Contributions from the Boyce Thompson Institute 12: 321-343.

Open Access This chapter is licensed under the terms of the Creative Commons Attribution-NonCommercial 2.5 International License (http://creativecommons.org/licenses/by-nc/ $2.5 /$ ), which permits any noncommercial use, sharing, adaptation, distribution and reproduction in any medium or format, as long as you give appropriate credit to the original author(s) and the source, provide a link to the Creative Commons license and indicate if changes were made.

The images or other third party material in this chapter are included in the chapter's Creative Commons license, unless indicated otherwise in a credit line to the material. If material is not included in the chapter's Creative Commons license and your intended use is not permitted by statutory regulation or exceeds the permitted use, you will need to obtain permission directly from the copyright holder.

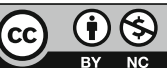

